\title{
THE USE OF COMMERCIAL ENZYMES TO IMPROVE DIETS CONTAINED PEANUT HAY ON PERFORMANCE OF GROWING RABBITS. \\ Mohamed, Rehab A. ${ }^{1}$; F. Abdel-Azeem ${ }^{2}$; S. A. Abdel-Fattah ${ }^{2}$ and M.H.M. Yacout ${ }^{1}$ \\ 1 By-Products Utilization Department, Animal Production Research Institute, Giza, Egypt. \\ ${ }^{2}$ Poultry Production Department, Fac.of Agri.,Ain Shams Univ., Egypt.
}

\begin{abstract}
This experiment was conducted to evaluate the effects of partial or complete replacement of clover hay by $\mathrm{PNH}(33.3,66.7$ and 100\%) with or without adding enzymes in the diets of growing rabbits. A total number of 72 unsexed, weaned New Zealand White rabbits of 6 weeks old were randomly divided into six experimental groups (12 rabbits/group). Six pelleted experimental diets were formulated to be approximately isocaloric and isonitrogenous to cover the recommended nutrient requirements of rabbits. Clover hay was replaced by peanut hay $(\mathrm{PNH})$ at the rate of $0,15,30$ without or with $1 \mathrm{gm}$ adding commercial enzymes per $\mathrm{kg}$ diet. The experimental period extended for 8 weeks. Results showed that, rabbit groups fed $15 \% \mathrm{PNH}$ diets either with or without enzyme addition had significantly higher final live body weight (LBW), daily body weight gain (DBWG), daily feed consumption (DFC), performance index and protein content of carcass meat as compared to $30 \% \mathrm{PNH}$ and control diets with or without enzyme. Rabbits fed diet contained 15\% PNH with enzyme had the best one for feed conversion ratio (FCR) compared with the other experimental groups. Higher economic efficiency was found with all diets contained $\mathrm{PNH}$ as compared to control diet without enzyme. Digestibility coefficients of the DM, $\mathrm{OM}, \mathrm{CP}, \mathrm{CF}$, and TDN were significantly increased for rabbits group received $15 \%$ $\mathrm{PNH}$ diet with enzyme addition while, the lower values were recorded with those fed control diet without enzyme. NFE digestibility increased by partial or complete substitution of clover hay with PNH with or without enzyme addition in the rabbit diets. Insignificant differences were found among dietary treatments in EE digestibility and DCP. Dressing percentage was significantly increased and hot carcass weight (\%) was insignificantly increased obtained with rabbits fed $30 \% \mathrm{PNH}$ with enzyme than other groups. Lower fat and ash content of carcass meat were noticed with rabbits fed control and $15 \% \mathrm{PNH}$ diets both with enzyme. However, adding the enzyme was resulted in lowering percentage of total non-carcass fat weight. Ammonia- $\mathrm{N}$ were significantly higher for rabbits fed $15 \%$ PNH diet without enzyme. Higher TVFA's was noticed with rabbits fed $15 \% \mathrm{PNH}$ containing diet with enzyme. Insignificant differences were found among rabbits fed the experimental diets in total protein, albumin and enzymes activity of liver (AST \& ALT). Higher globulin and Total cholesterol levels found for rabbits fed $30 \% \mathrm{PNH}$ diet with enzyme than other groups. Glucose level was significantly higher for the control diets compared with diets containing $\mathrm{PNH}$. Urea and creatinine levels in the blood were comparable for all diets except for control diets with enzyme, as it recorded lower concentration. It might be safe to conclude that, growing rabbits fed diets containing $\mathrm{PNH}$ supplemented with commercial enzymes could be used as feed supplement in the diet of rabbits. So, it can be used $15 \% \mathrm{PNH}$ as a good replace of clover hay without any adverse effect on rabbit performance.
\end{abstract}

Keywords: peanut hay, clover hay, rabbit, performance, carcass traits, economic efficiency. 


\section{INTRODUCTION}

Rabbits are characterized by high feed efficiency for producing animal protein for human consumption. The shortage of feedstuffs is one of the major limiting factors for increasing the animal production. The wild rabbits, being a herbivorous, consume a high proportion of plant as an integral part of their diet. Moreover, rabbits have the advantage of utilizing forages and byproducts as a major the diet components since forages represent an important part of the rabbits diet. Rabbits meat production using local sources especially forages can help to overcome the dietary protein gap (lebas, 1983). Incorporation of cheap un-conventional feedstuffs such as agroindustrial by-products in the animal diets participate in solving the problem of feed shortage, decrease the feeding cost and alleviate the polllution problems. Therefore, attempts have been carried out to search for alternative non-conventional low price by-products, which could be used in animal feeding. Especially, many attempts made to introduce some forages which suit the Egyptian climate and conditions in newly reclaimed lands.

Peanut hay is one of the most important crop by-products in summer especially in the reclaimed sandy soil land. Peanut hay $(\mathrm{PNH})$ is available in Egypt but it use is sometimes limited due to the poor understanding of their nutritional and economic value as well as proper use in ruminant diets. Peanut hay can be used as a good substitution for either alfalfa or clover hay in ruminant due to its high protein ratio as reported by Awadalla et al.. (1997). Peanut hay is as an excellent feed for rabbits. EL-Adawy and Borhami (2001) and Ibrahim (2000) who reported that, partial or complete replacement of clover hay with Peanut hay $(\mathrm{PNH})$ resulted in higher growth performance, economic efficiency, nutrients digestibility and viability of growing rabbits. Enzymes are additives used to improve the performance of rabbits through the reducing viscosity of intestinal contents and improving nutritive value of the diet (Bedford and Morgan, 1996 and El-Tantawy et al.., 2001). The present study was carried out to evaulate the effects of partial or complete replacement of clover hay by $\mathrm{PNH}(33.3,66.7$ and 100\%) with or without adding enzymes in the diets of growing rabbits on growth performance, economic efficiency, nutrients digestibility coefficients, carcass traits, caecum activity and some blood components.

\section{MATERIALS AND METHODS}

The present study was carried out at EL-Nubaria Research Station of the Animal Production Research Institute, Egypt, during the period from January 2007 till April 2007. A total number of 72 unsexed, weaned New Zealand White (NZW) of 6 weeks old were randomly divided into six experimental groups (12 rabbits/group). Each group was subdivided into four replicates, each of 3 rabbits and the initial live body weights of all experimental groups were almost equal $959 \pm 0.05 \mathrm{~g}$.

Six pelleted experimental diets were formulated to be approximately isocaloric and isonitrogenous. All experimental diets were formulated to cover the recommended nutrient requirements of rabbits according to NRC (1977) 
and Cheeke (1987). Clover hay was replaced by peanut hay (PNH) at the rate of 0,15 , and 30 without or with $1 \mathrm{gm}$ adding commercial enzymes per $\mathrm{kg}$ diet. Samples of experimental roughages (clover hay and peanut hay) were used for proximate analysis using the A.O.A.C methods (1995) and the results are presented in Table (1). Ingredients and chemical composition of the experimental diets are summarized in Table (2). The enzymatic composition of the utilized commercial enzyme product (CAPLIX): contained the following concentrations (IU) of enzymes, $100 \times 10^{6}$ Cellulase, $250 \times 10^{3}$ Amylase, $7 \times 10^{3}$ Arabinase, $30 \times 10^{3}$ Pectinase, $150 \times 10^{3}$ Phytase, $10 \times 10^{3}$ Lipase, $4 \times 10^{3}$ Protease, $1.5 \times 10^{6}$ Xylanase, $10 \times 10^{3}$ Alpha Galactosidase and $10 \times 10^{3}$ Beta Glucosidase. Rabbits were housed in galvanized metal wire cages $(60 \times 50 \times 40$ and provided with feeders and automatic watering system, ( 3 rabbits per each cage). Rabbits were individually weighed at the beginning of the experiment, then at weekly intervals until the end of the experiment. The experiment was lasted for 8 weeks.

Table (1): Chemical composition of Clover hay (CH) and Peanut hay (PNH) :

\begin{tabular}{|l|c|c|}
\hline Item & Clover hay (CH) & Peanut hay (PNH) \\
\hline Dry matter (DM) & 89.67 & 88.41 \\
\hline Organic matter (OM) & 86.75 & 89.13 \\
\hline Crude protein (CP) & 12.18 & 12.22 \\
\hline Crude fiber (CF) & 26.45 & 29.54 \\
\hline Ether extract (EE) & 1.67 & 2.85 \\
\hline Nitrogen free extract (NFE) & 46.45 & 44.52 \\
\hline Crude ash & 13.25 & 10.87 \\
\hline Fiber fractions & & 31.87 \\
\hline \hline NDF & 59.12 & 20.12 \\
\hline ADF & 36.43 & 4.68 \\
\hline ADL & 7.26 & 11.75 \\
\hline Cellulose & 22.69 & 15.44 \\
\hline Himecellulose & 29.17 & \\
\hline
\end{tabular}

At the last week of the experiment, digestibility trials were conducted using 18 rabbits ( 3 rabbits from each treatment). Rabbits were housed individually in metabolism cages that allow faeces and urine separation. The preliminary period continued for 7 days and the collection period extended for 3 days. Feed intake was exactly determined. Faeces were daily collected, weighed and dried at $60-70^{\circ} \mathrm{C}$ for 24 hours, bulked, finely ground and stored for chemical analysis. The apparent digestibility coefficients of DM, OM, CP, $\mathrm{CF}, \mathrm{EE}$ and NFE for the tested diets were estimated. The chemical composition of the clover hay, peanut hay $(\mathrm{PNH})$, experimental diets and faeces were analyzed according to A.O.A.C.(1995). The total digestible nutrients (TDN) were calculated according to the classic formula (Cheeke et al.., 1982). The digestible energy (DE) of peanut hay (PNH) was calculated according to Fekete and Gippert (1986) by applying the equation:- DE $(\mathrm{kcal} / \mathrm{kg})=4253-32.6(\mathrm{CF} \%)-144.4($ total $\mathrm{ash} \%)$. 
Table (2): Composition of the experimental diets and their chemical analysis.

\begin{tabular}{|c|c|c|c|}
\hline Ingredients (\%) & Control & $15 \%$ peanut hay & $30 \%$ peanut hay \\
\hline Yellow corn & 26.5 & $r V$, & 24.0 \\
\hline Soy bean meal (44\% CP) & $1 \varepsilon, 1$ & 10, & $10,$. \\
\hline Clover hay & $r \cdot, \cdot$ & $10,$. & $\cdot, \cdot$ \\
\hline Wheat bran & ro,o & $r \varepsilon, \Lambda$ & $r V, \Lambda$ \\
\hline Peanut hay & $\cdot, \cdot$ & 15.0 & 30.0 \\
\hline Limestone & $\cdot, 9$. & $\cdot 9$. & $\cdot, 9$. \\
\hline Di-calcium phosphate & 1.30 & 1.30 & 1.30 \\
\hline Salt (NaCl) & 0.50 & 0.50 & 0.50 \\
\hline Vit.\&Min premix* & 0.30 & 0.30 & 0.30 \\
\hline DL-Methionine & 0.20 & 0.20 & 0.20 \\
\hline Total & 100.00 & 100.00 & 100.00 \\
\hline \multicolumn{4}{|l|}{ Chemical analysis $\#$} \\
\hline \multicolumn{4}{|l|}{ A- Determined analysis } \\
\hline Organic matter (OM\%) & $9 r, \cdot r$ & $94, Y 7$ & 94,71 \\
\hline Crude protein (CP\%) & 16.25 & 16.23 & 16.48 \\
\hline Crude fiber (CF\%) & 12.40 & 12.78 & 13.53 \\
\hline Ether extract (EE\%) & r, YA & $r, Y_{T}$ & $r, \wedge \varepsilon$ \\
\hline Nitrogen free extract (N.F.E. \%) & 61.09 & 60.99 & 59.83 \\
\hline Crude ash (\%) & 7.00 & 8.36 & 8.45 \\
\hline \multicolumn{4}{|l|}{ B- Calculated analysis } \\
\hline DE (kcal/kg) & 2601 & 2587 & 2554 \\
\hline Methionine + cystine (\%) & 0.76 & 0.71 & $0 . .66$ \\
\hline Lysine (\%) & 0.91 & 0.79 & 0.69 \\
\hline Calcium (\%) & 1.14 & 1.05 & 1.00 \\
\hline Total phosphorous (\%) & 0.70 & 0.69 & $0 . .65$ \\
\hline
\end{tabular}

- One kilogram of premix provides: 2000.000 IU vit. A, 150.000 IU vit. D, $8.33 \mathrm{~g}$ vit. E, $0.33 \mathrm{~g}$ vit $\mathrm{k}, 0.33 \mathrm{~g}$ vit. $\mathrm{B} 1,1.0 \mathrm{~g}$ vit. $\mathrm{B} 2,0.33 \mathrm{~g}$ vit. $\mathrm{B} 6,8.33 \mathrm{~g}$ vit. $\mathrm{B} 5,1.7 \mathrm{mg}$ vit. $\mathrm{B} 12,3.33 \mathrm{~g}$ pantothenic acid, $33 \mathrm{mg}$ Biotin, $0.83 \mathrm{~g}$ folic acid, $200 \mathrm{~g}$ choline chloride, $11.7 \mathrm{~g} \mathrm{Zn,} 12.5 \mathrm{~g} \mathrm{I}$, $16.6 \mathrm{mg} \mathrm{SE}, 16.6 \mathrm{mg} \mathrm{Co}, 66.7 \mathrm{~g} \mathrm{Mg}$ and $5 \mathrm{~g} \mathrm{Mn}$.

\# As DM basis

At the end of the growth trial, four randomly chosen rabbits (14 weeks of age) representing each group were slaughtered according to the standard technique of Cheeke et al.. (1982). Dressing percentage included relative weights of carcass, giblets and head. Blood samples were collected at slaughtering time in heparinized glass tubes (4 samples per each treatment group). Blood plasma was separated by centrifugation at $3000 \mathrm{rpm}$ for 15 minutes. The collected plasma was stored at $-20^{\circ} \mathrm{C}$ until assay. Values of total protein, albumin, total cholesterol, glucose, urea-N, creatinine and liver enzyme activities (AST and ALT) were determined by commercial kits (Boi-diagnostics Company, Egypt). The globulin values were calculated. Values of $\mathrm{pH}$ for stomach and caecum contents were measured immediately by using a digital $\mathrm{pH}$ meter. The volatile fatty acids were determined according to Conway (1958).

The economic efficiency (EEf) was calculated according to the following equation: $E E f=A-B / B X 100$. where $A$ is selling cost of obtained gain (LE per kg) and $B$ is the feeding cost of this gain. The performance index 
(PI) was calculated according to the equation described by North (1981) as follows: $\mathrm{PI}=$ Live body weight $(\mathrm{Kg}) /$ Feed conversion $\times 100$

Data were analyzed according to statistical analysis system User's Guide, (SAS, 1998). Separation among means was carried out by using Duncan's multiple range test (Duncan,1955). The model was as follows: $Y_{i j}=\mu+T_{i}+e_{i j}$ Where: $Y_{i j}=$ The observation on the $t^{\text {th }}$ treatment $\mu=$ Overall mean $T_{i}=$ Effect of the $t^{\text {th }}$ treatment $\quad e_{i j}=$ Random error treatment.

\section{RESULTS AND DISCUSSION}

\section{1- Growth performance:}

\section{1- Live body weight (LBW) and daily weight gain (DWG):}

Results presented in Table (3) revealed that, LBW at $6^{\text {th }}$ week of rabbits age was insignificantly differed $(P>0.05)$ among experimental treatments. At the $14^{\text {th }}$ week of age, rabbits group received diet containing $15 \% \mathrm{PNH}$ with enzyme addition gave the highest LBW (2784.4g), followed by those fed on the same diet without enzyme addition $(2700.0 \mathrm{~g})$ and either $30 \% \mathrm{PNH}$ containing diets with or without enzyme (2520 and $2505.6 \mathrm{gm}$, respectively) when compared with control diets with or without enzyme (2425.3 and 2417.7 $\mathrm{gm}$, respectively). However, statistical analysis for LBW at 14 weeks of age showed highly significant $(P \leq 0.01)$. This may be due to an increase of most nutrients digestibility and nutritive value for groups received 15\% PNH diets with or without enzyme when compared to any of the other groups.

During the period of 6-14 weeks of age, rabbits group fed diet contained $15 \% \mathrm{PNH}$ with enzyme was recorded the higher $(\mathrm{P} \leq 0.01) \mathrm{DBWG}$ $(34.23, \mathrm{~g} / \mathrm{h} / \mathrm{d})$, followed by the same diet but without enzyme $(31.15, \mathrm{~g} / \mathrm{h} / \mathrm{d})$. While all rabbits in other groups had significantly lower $(P<0.01)$ DBWG. However, groups fed $30 \% \mathrm{PNH}$ containing diets were showed to had higher DBWG (27.66 and 27.95, $\mathrm{g} / \mathrm{h} / \mathrm{d}$, respectively) than the control groups (26.07 and $26.21, \mathrm{~g} / \mathrm{h} / \mathrm{d}$, respectively) without significant differences. Qnetiek et al.. (1999) reported improved weight gains in goats when legumes were used to supplement roughage based diet, as $\mathrm{PNH}$ considered to be one of the legume plants. These results are in agreement with those obtained by Afifi (1999) and Ibrahim (2000) who noticed higher body weight gain by substituting 66.7 or $100 \%$ of the clover hay with $\mathrm{PNH}$ in diets of growing rabbits. EL-Adawy and Borhami (2001) showed that replacement of clover hay with $\mathrm{PNH}$ up to $50 \%$ resulted in higher growth performance compared with the control group. It was also noticed that adding the enzyme had no significantly effect in the DBWG for the control and 30\% PNH containing diets.

- Daily feed consumption (DFC) and feed conversion ratio (FCR):

Through the overall period (6-14 weeks of age) of the experiment, rabbits fed diets contained $15 \% \mathrm{PNH}$ with or without enzyme were showed higher $(P \leq 0.01)$ DFC compared to other groups (100.01and 99.26, $/ \mathrm{h} / \mathrm{d}$, respectively), with insignificant of adding enzyme. No significant effect of enzyme was noticed with diets contained $30 \% \mathrm{PNH}(94.07$ and $93.70, \mathrm{~g} / \mathrm{h} / \mathrm{d}$, respectively) with insignificant differences with the control diet with enzyme. 
No significant effect of enzyme was noticed with rabbits fed diets contained $30 \% \mathrm{PNH}$, as DFC was 99.43 and $98.70(\mathrm{~g} / \mathrm{h} / \mathrm{d})$ for the diet without and with enzyme, respectively. The enzyme had positive effect with rabbits fed the control diet, as adding the enzyme was increased DFC by about $11.21 \%$. The increase of DFC with rabbits fed PNH diets may be due to the higher digestibility of most nutrients (El-Adawy and Borhami, 2001).

Through the overall period (6-14 weeks), whereas rabbits fed diet contained $15 \%$ PNH with enzyme found to have the better one for FCR (2.95, $\mathrm{g}$ feed/g gain), but with significant differences $(P \leq 0.01)$ compared with the other experimental groups. In the meantime, the control groups with enzyme was found to the worst one $(3.77, \mathrm{~g} / \mathrm{g}$ gain) but with insignificant differences with group of rabbits fed $30 \% \mathrm{PNH}$ with enzyme $(3.42, \mathrm{~g} / \mathrm{g}$ gain). Other groups were significantly comparable to each others, as FCR were $3.32,3.21$ and 3.41 (g feed/g gain) for control diet without enzyme, that contained $15 \%$ $\mathrm{PNH}$ without enzyme and that contained $30 \% \mathrm{PNH}$ without enzyme as well, respectively. The improvements in FCR value with $15 \% \mathrm{PNH}$ compared to other diets may due to first to the increase in feed intake, secondly to the more digestible nutrients intake by rabbits (Afifi, 1999 and Ibrahim, 2000). These results are in agreement with those reported by Amber and Osman (2001) found that, LBW, DBWG and FCR significantly improved with supplementing enzyme into rabbits diet or water when compared to control diet. Similarly, Sarhan (2001) observed that, addition of enzyme into rabbit's diets improved LBW, BWG and FCR. Therefore, enzymes addition could improve the digestion efficiency by increasing carbohydrates digestibility before the caecum which could avoid its effect on the diarrhea, as suggested by Sequeira et al. (2000). This study may be proved that, PNH can be as a replacer to clover hay as a source of fiber without adverse on health rabbits.

\section{3- Economic evaluation}

Higher $(P \leq 0.01)$ total revenue and net revenue were recorded by rabbits fed $15 \% \mathrm{PNH}$ diet with enzyme, followed by same diet without enzyme when compared to the other groups. Higher $(P \leq 0.01)$ economic efficiency was found with all diets contained PNH without significant differences among themselves and control diet without enzyme. However, from the economic point of view, the profitability of using PNH in partial substitution for berseem hay in rabbit diets are depending on the price of these feedstuffs. Increase berseem hay substitution with $\mathrm{PNH}$ decreased the economic efficiency value. Such decrease may be due to the observed decrease in most nutrients digestibility and the nutritive values (Table, 3) which negatively affected growth performance and economic efficiency of growing rabbits. The results of economic efficiency support those obtained by Ibrahim (2000) who reported that the economic efficiency of feeding diets at morale age was higher with PNH substitution of clover hay. The same trend of these results were reported by El-Adawy and Borhami (2001), who found same trend of feed efficiency with substitution berseem hay with PNH (50\%).

Performance index was significantly $(\mathrm{P} \leq 0.01)$ higher for $15 \% \mathrm{PNH}$ diet with enzyme (66.26), followed by the same diet without enzyme (55.14), compared to any of the other groups. However, the enzyme had positive 
effect for either economic efficiency or performance index only with $15 \% \mathrm{PNH}$ level, and not for $30 \%$ or nil level of PNH.

1.4- Mortality rate:

It is interesting to notice that, the morality rate during the experimental period of growth was zero among dietary treatments. This may be an indication that growing rabbits can tolerate (utilized) different dietary levels of $\mathrm{PNH}$ in the diet. This result agreed with those reported by Adawy and Borhami (2001).

2- Nutrients digestibility coefficients and nutritive values:

Concerning digestibility coefficients of the DM, OM and $\mathrm{CP}$, the results showed that the higher $(P \leq 0.01)$ values recorded for rabbits group received diet containing $15 \%$ PNH with enzyme addition while, the lower values were recorded with rabbits given control diet without enzyme. Insignificant differences were found among dietary treatments in EE digestibility coefficients. Digestibility coefficients of CF were significantly $(P \leq 0.01)$ increased with rabbits group fed on diet contained $15 \% \mathrm{PNH}$ plus enzyme and also those given diet contained 30\% PNH plus enzyme when compared with other groups.(Table, 4).

The apparent digestibility coefficients of NFE increased by partial or complete substitution of clover hay with $\mathrm{PNH}$ with or without enzyme addition in the rabbit diets.

The average nutritive values in terms of TDN ranged from 60.79 to 65.58 being the highest value for rabbits given 15\% $\mathrm{PNH}$ plus enzyme diet (65.58) followed by $15 \% \mathrm{PNH}$ without enzyme or $30 \% \mathrm{PNH}$ with enzyme diets $(63.90$ and 63.70$)$ but, the lowest value $(60.79)$ for control diet. It was observed that, there were improvements markedly in TDN by dietary PNH increased in the growing rabbit diets. Also, it was obvious that, the values of TDN increased were good indicator for improvements of rabbit performance (especially, feeding $\mathrm{PNH}$ up to $15 \%$ with enzyme addition). The response of adding enzyme to diets was clearly noticed as well for TDN values, except for the control diet, it had no effect. Nutritive values expressed as DCP (\%) were insignificant difference $(P>0.05)$ among diets. However, it was more for $15 \%$ PNH with enzyme $(9.71 \%)$ and less for $30 \%$ PNH without enzyme $(9.13 \%)$. The enzyme had improved DCP values for all diets but without significant differences. These results coincided with reported by Hassan (1999) who found that the nutrient digestibility coefficients increased as the level of PNH increased up to $50 \%$ of dietary clover hay in growing rabbit's diets. Also, the findings reported herein agree with those of Awadalla et al.. (1997) when $\mathrm{PNH}$ was added to lambs diets. In the same trend, El-Adawy and Borhami (2001) found that increasing level of PNH in rabbit diets to replace berseem hay was increased apparent digestibility coefficients. Also, Afifi (1999) was reported same results as it found in this study. However, Ibrahim (2000) reported that the partial or complete substitution of clover hay with PNH diet not significantly increased TDN and DCP values of diets compared to the control diet. 
Mohamed, Rehab A. et al.

T3-4

4918 
The present data were cleared that adding the enzyme to the diets was positive in improving the nutrients digestibility coefficients, except for DM, $\mathrm{OM}, \mathrm{CF}$ and NFE of the control diet. Similar results were reported by Ibrahim et al. (1999) who found that, adding enzymes into rabbits diets significantly improved the digestibility coefficient of DM, CP and EE. Sarhan (2001) indicated that, addition of commercial enzymes to rabbit diets significantly increased DM, OM, CP, CF and EE as well as nutritive values. The benefits results from dietary addition of enzymes could be attributed to the partial degradation of the soluble glucan chain, reducing the viscosity of the intestinal contents and improving nutrient absorption (Bedford and morgan, 1996 and El-Tantawy et al., 2001). Generally, the results showed that, nutrients digestibility coefficients and nutritive values increased when fed animals $15 \% \mathrm{PNH}$ plus enzyme diet compared to any of the other diets. These results, may be explain the increase in daily weight gain by rabbits which fed $15 \%$ PNH plus enzyme diets during the period of growth (10-14 weeks of rabbits age).

3-Carcass traits, caecum activity and chemical analysis of rabbits meat:

Higher $(\mathrm{P} \leq 0.05)$ dressing percentage was obtained with rabbits fed $30 \%$ PNH with enzyme $(67.48 \%)$, followed by those fed diet contained same diet without enzyme and 15\% PNH with enzyme (64.80\%) and (64.63\%). Control diet with and without enzyme and that contained 15\% PNH without enzyme were recorded intermediate values. Hot carcass weight (\%) was insignificantly increased for rabbits fed diet containing 30\% $\mathrm{PNH}$ with enzyme followed by those received diet containing 15\% PNH plus enzyme and 30\% $\mathrm{PNH}$ without enzyme. While, the lowest carcass weight (\%) for rabbits group $15 \% \mathrm{PNH}$ without enzyme. (Table, 5). These results were confirmed by Afifi (1999) who reported that groups of rabbits fed diets including PNH (33.33 and $66.67 \%$ ) in place of clover hay were somewhat higher in dressing weight and the total edible parts weight than in those fed the control diet.

No significant differences $(P>0.05)$ for relative weights of head, giblets and blood among experimental treatments. El-Adawy and Borhami (2001) who found that constituents of berseem hay with $\mathrm{PNH}(50 \%)$ had significantly higher hot and cold carcass weight. Afifi (1999) reported that no significant differences in carcass characteristics were obtained in rabbits fed diets contained $33.33 \% \mathrm{PNH}$ in place of clover hay.

Rabbits fed diet contained 15\% PNH without enzyme was recorded higher $(P \leq 0.05)$ total non-carcass fat weight percentage. Lower $(P<0.05)$ weight percentage was found with rabbits fed the control diet with enzyme. However, adding the enzyme was resulted in lowering percentage weight of total noncarcass fat (Table, 5). The obtained results of enzyme addition effect agreed with those of Amber and Osman (2001) who reported that, dressing percentage of rabbits was significantly increased when the enzymes added to diet or water. On the other hand, Sarhan (2001) showed that, there were no significant differences increase traits of rabbits fed diets supplemented with commercial enzyme.

Values of caecum and stomach $\mathrm{pH}$ were insignificantly different among the experimental rabbits. These values of $\mathrm{pH}$ are within the normal ranges reported by Lebas et al. (1997) and Abdel-Azeem et al. (2004 and 2006). 
Ammonia- $\mathrm{N}$ values were significantly differed $(\mathrm{P} \leq 0.05)$ among rabbit groups, whereas it was $28.89(\mathrm{mg} / 100 \mathrm{ml} \mathrm{RL})$ for rabbits fed diet contained $15 \% \mathrm{PNH}$ without enzyme, while it lower $(\mathrm{P} \leq 0.05)$ for control diets $(24.58$ and 23.37, $\mathrm{mg} / 100 \mathrm{ml} \mathrm{RL}$ ) with and without enzyme. Total VFA's were also significantly differed $(P \leq 0.05)$ among rabbits fed the experimental diets. Higher ( $P \leq 0.05)$ TVFA was noticed with rabbits fed 15\% PNH containing diet with enzyme (115.67, meq/ $100 \mathrm{ml} \mathrm{RL})$.

No significant differences $(P>0.05)$ were found among carcasses meat of rabbits fed the experimental diets for DM content (Table 6). Diets contained $15 \% \mathrm{PNH}$ with or without enzymes were showed higher $(P \leq 0.01)$ protein content of carcass meat of rabbits fed such diets $(66.98$ and $67.02 \%$, respectively as compared to the other groups. Fat content of carcasses meat was higher $(P \leq 0.01)$ for rabbits fed all experimental diets except for those fed control or $15 \% \mathrm{PNH}$ both with enzyme. Ash content of rabbits meat fed diets 15 and $30 \% \mathrm{PNH}$ without enzyme was higher $(P \leq 0.01)$ compared to other diets $(17.78$ and $18.44 \%$, respectively). Lower $(P<0.01)$ ash content was noticed with rabbits fed control and 15\% PNH diets with enzyme (16.01 and $16.30 \%$, respectively). However, the chemical composition of rabbits meat studied herein was in the same range by Blaso et al.. (1992). Results of Ngodigha et al.. (1994), Afifi (1999) and Ibrahim (2000) are in harmony with the obtained results in this study. And also, the present results agreed with those reported by Amber and Osman (2001) who found that, addition of enzyme to diet or water did not significantly any component of the meat composition (DM, CP, EE and Ash content).

\section{4- Blood biochemical components:}

No significant differences $(P>0.05)$ were found among rabbits fed the experimental diets for their blood concentration of both total protein and albumin (g/dl) (Table, 6). Total protein was ranged from 6.79 and $7.20(\mathrm{~g} / \mathrm{dl})$ for rabbits fed the control and $30 \% \mathrm{PNH}$ without enzyme. And also, albumin was ranged between 4.29 and $4.55(\mathrm{~g} / \mathrm{dl})$ for rabbits fed the control and $30 \%$ $\mathrm{PNH}$ without enzyme as well. Higher $(P \leq 0.01)$ globulin level $(\mathrm{g} / \mathrm{dl})$ was found for rabbits fed $30 \% \mathrm{PNH}$ diet with enzyme $(2.88)$. Lower $(P \leq 0.01)$ globulin level was noticed with rabbits fed $15 \%$ PNH diets without enzyme (2.45). Results obtained in this study were in agreement with findings of Melby and Altman (1974) found that, normal values of some blood components in rabbits, total protein $(\mathrm{g} / \mathrm{dl})$ from 4.9 to 7.20 , albumin $(\mathrm{g} / \mathrm{dl})$ from 3.3 to 5.1 and globulin $(\mathrm{g} / \mathrm{dl})$ from 1.85 to 2.7 or 1.9 to 3.6 . Total protein in the blood may reflect the nutritional status of the animal (O'kelly, 1973). Kumar et al.. (1980) found positive correlation between total protein content in the blood and dietary protein. Positive correlation between digestible protein intake and plasma albumin (Hewett, 1974).

Total cholesterol level was showed to be higher $(P \leq 0.01)$ with rabbits fed $30 \%$ PNH diet without enzyme $(92.32, \mathrm{mg} / \mathrm{dl})$. Lower $(\mathrm{P} \leq 0.01)$ level was noticed with the control diet with enzyme (81.96, mg/dl). Enzyme had negative effect on the concentration of blood cholesterol, especially with $30 \%$ $\mathrm{PNH}$, it had higher effect as it decreased from 92.32 to 85.34 (7.56\%). 
J. Agric. Sci. Mansoura Univ., 33 (7), July, 2008

T5-6

4921 
Concentration of blood glucose $(\mathrm{mg} / \mathrm{dl})$ was significantly higher for the control diet with enzyme $(81.04, \mathrm{mg} / \mathrm{dl})$ compared with $30 \% \mathrm{PNH}$ diets $(74.77$ and $77.65, \mathrm{mg} / \mathrm{dl})$ and $15 \% \mathrm{PNH}$ diet without enzyme $(77.98, \mathrm{mg} / \mathrm{dl})$. However, enzyme had positive effect with significant effect for $30 \% \mathrm{PNH}$ diets. Urea blood concentration (mg/dl) was comparable for all diets except for control diets with enzyme, as it recorded lower $(P \leq 0.01)$ concentration $(39.01, \mathrm{mg} / \mathrm{dl})$. The same trend was noticed for creatinine levels.

Higher $(P \leq 0.01)$ hemoglobulin level $(g / d l)$ was recorded for rabbits fed control and 15\% PNH diets, hemoglobulin level was ranged from 13.28 and $13.56(\mathrm{~g} / \mathrm{dl})$ for $15 \% \mathrm{PNH}$ diet without enzyme and the control diet with enzyme, respectively. Insignificant differences $(P>0.05)$ were found among rabbits for their blood AST and ALT concentrations which was due to feeding $\mathrm{PNH}$. Values of blood urea, AST and ALT were far less than that reported by Zanaty (2002), especially with enzyme supplementation. This could be due to the active effect of Biogen level used in this study compared to the enzyme used in our study. The results of AST and ALT are in good agreement with those reported by Chiericato et al. (1985) and lie within the normal level. The present results of blood components are in agreement with those of Amber and Osman (2001) reported that, the glucose and triglycerides were significantly increased by adding enzyme to diet or water. This increase may be due to the role of the effective amount of Amylase, Beta glucanase and Xylanase. On the other hand, Sarhan (2001) observed that, there were not significant differences total protein with its fractions, total lipids, total cholesterol, creatinine and ALT. While, glucose level was significantly decreased and AST was significantly increased with adding enzymes into rabbit. Generally, the obtained results of blood components in the present study were within the normal values reported by Hillyer and Quesenberry (1994).

The general conclusion indicated that, $\mathrm{PNH}$ could be successfully for feeding growing rabbits up to $30 \%$ level without any deleterious effects on the rabbit performance and economic evaluation. And concluded from this study that substitution of clover hay with about $15 \% \mathrm{PNH}$ with adding enzyme can be recommended in formulating rabbits diet in order to have a good performance with less feeding cost.

\section{REFERENCES}

A.O.A.C. (1995). Association of Official Analytical Chemists. Official Methods of Analysis, $16^{\text {th }}$ Edition, Washington, USA.

Abdel-Azeem, F and Abdel-Reheem, M.A.T. (2006). Effect of supplemental copper and fresh garlic on performance and some biochemical changes in growing rabbits. Egyptian Journal Rabbit Science, 16(2): 341-366.

Abdel-Azeem, F; Khorshed, M.M and El-Hommosany, Y. M. (2004).Growth performance and some PNHysiological measurements of growing rabbits fed diets supplemented with either antibiotics or probiotics Egyptian Journal Nutrition \& Feeds, 7 (2): 207-221. 
Abdel-Samee, A.M;el-Gndy, K.M and Ibrahim, H. (1994). Rabbits growth and reproductive performance as influenced by feeding desert forage (Acacia Saligina and Atriplex Nummlaria), at North Sinai, Egyptian J. of rabbits Sci ; 4: 25.

Afifi, S. (1999). Digestibility and acceptability of some agriculture by-products by growing rabbits. M.Sc. Thesis, Faculty of Agriculture, Cairo University. Egypt.

Amber, Kh., and Mona Osman. (2001). Effect of prozme supplementation to diet or water of some nutritional and physiological traits of weanling New Zealand White rabbits. Egyptian Journal Rabbit Science, 11(2): 207-219.

Awdalla, I. M; M. I. Mohamed; M.A.M Ibrahim and A. K. EL-Asheer (1997). Efficiency of using groundnut hay in rations of Ramani Lambs. Egypt. J of Animal Production, 34:125.

Bedford and morgan. (1996). The use of enzymes in poultry diet. World's Poult. Sci. J, 52: 61.

Cheeke, P. R. (1987). Rabbit feeding and nutrition. Academic press, Orlando, Florida USA.

Cheeke, P. R., N.M. Patton and G.S. Tempelton (1982). Rabbit production. $5^{\text {th }}$ Edition, Interstate Printers and Publishers Danville II., USA.

Hewett, C. D. (1974). On the causes and effects of variations in the blood profile of the Swedish dairy cattle. Acata Vet. Scand, 50, 152 (Suppl. 1).

Chiericato, G.M.; Schiapelli, M.P. and Filotto, U. (1985). Studo della relazioni esistenti fra prestazioni produttive eprobilo metabolico nel coniglio. Estratto da Coniglicoltura XXLL, N. 12.

Conway, E.J. (1958). Micro diffusion analysis and volumetric error. $4^{\text {th }}$ Edition. The McMillian Co., New York, USA.

Duncan, D. B. (1955). Multiple range and multiple $F$ test. Biometrics, 11:1-42.

EL-Adawy and Borhami (2001). Utilization of peanut hay and dried sugar beet tops in feeding of growing rabbits. Egyptian J. Nutrition and Feeds (2001) 4: 869-883.

El-Tantawy, S.M.T., Sami, Z. Meshreky, Fadia M. Nosseir and Hanna, M.F.S. (2001). Effect of some feed additives on: 1. Productive performance, carcass traits and some blood constituents of growing Buscat rabbit. Egyptian J. Nutrition and feeds, 4:931.

Fekete, S and T. Gippert (1986). Digestibility and nutritive value of nineteen important feedstuffs for rabbits. J. Appl. Rabbit Res., 9 (3) : 103.108.

Hassan, A. (1999). Nutritional studies on mixture of green and dry roughages in rabbits. M. Sc. Thesis, Faculty of Agriculture, Cairo University, Egypt.

Hillyer, E.V. and Quesenberry, K.E. (1994). Ferrets, Rabbits and Rodents clinical medicine and surgery. Basic Approach to veterinary care Rabbits 165-166.

Ibrahim, M. (2000). Effect of feeding system and supplemented diet with enzymatic preparation on performance of growing rabbits.J. Productivity and Develop, 5: 179.

Ibrahim, M. R. M. (2000). Efficiency of using peanut hay and carrot-tops hay for feeding growing rabbits. Egyptian Journal of Rabbi Science, $10: 147$. 
Ibrahim, M.R.M., K.Y. El-Nagmy and S.M. Farghly (1999).Effect of replacement of barley by dried barley radicelles with or without kemzyme on performance of growing rabbits. Egyptain Journal of Rabbit Science, 9 (1) 61-71.

Kumar, N .; Singh, U. B and Verma, D. N. (1980). Effect of different levels of dietary protein and energy on growth of male buffalo cavles. Indian $\mathrm{J}$. Sci., 51: 513-519.

Lebas, F. (1983). Small scale rabbits production feeding and management system. World Animal Review, 46: 11-17.

Lebas, F.; Coudert, P.; Rochambeau, H. and Thebauff, R. G. (1997). Nutrition and feeding. THE RABBIT. Husbandry, heath and production, pp 1921.

Melby, E.C. and Altman, N. H. (1974). Biochemical constituents of serum in: Hand Book of Laboratory Animal Science E.C. Merck (1974).

N.R.C. National Research Council, (1977). Nutrient requirements of rabbits. National Academy of Science, Washington, D.C.

Ngodigha, E.M.; B.T. Sese and I.O.A. Adeleye. (1994). Dietary fiber utilization and growth performance of yong rabbits fed on rabbit concentrates replaced with graded levels of groundnut haulms. Journal of Applied Animal Research, 5:21.

North, M.O. (1981). Commercial Chicken. Production Annual. 2nd Edition, AV., publishing company I.N.C., Westpost Connicticut, USA.

O'kelly, T.C. (1973). Seasonal variations in the plasma lipids of genetically different types of cattle steers on different diets. Comparative Bio., And Physio., $44 \mathrm{~A}, 303$.

Sarhan, M.A. (2001). Effect of protein level and supplementation of enzyme preparation in diets of growing rabbits. $8^{\text {th }}$ Sci. Con. on Animal Nutrition. Part (II). Egyptian J. Nutrition and feeds 4:831.

SAS, (1998). SAS. Procedure Guide. Version 6.12 Ed. "SAS Institute Inc. Cary, NC.USA.

Zanaty, G.A. (2002). The use of Bisgen as a natural growth promote for growing New Zealand White rabbits. $3^{\text {rd }}$ Sci. Con. on Rabbit Prod. in Hot Climates, 8-11, Oct., 2002, : 507.

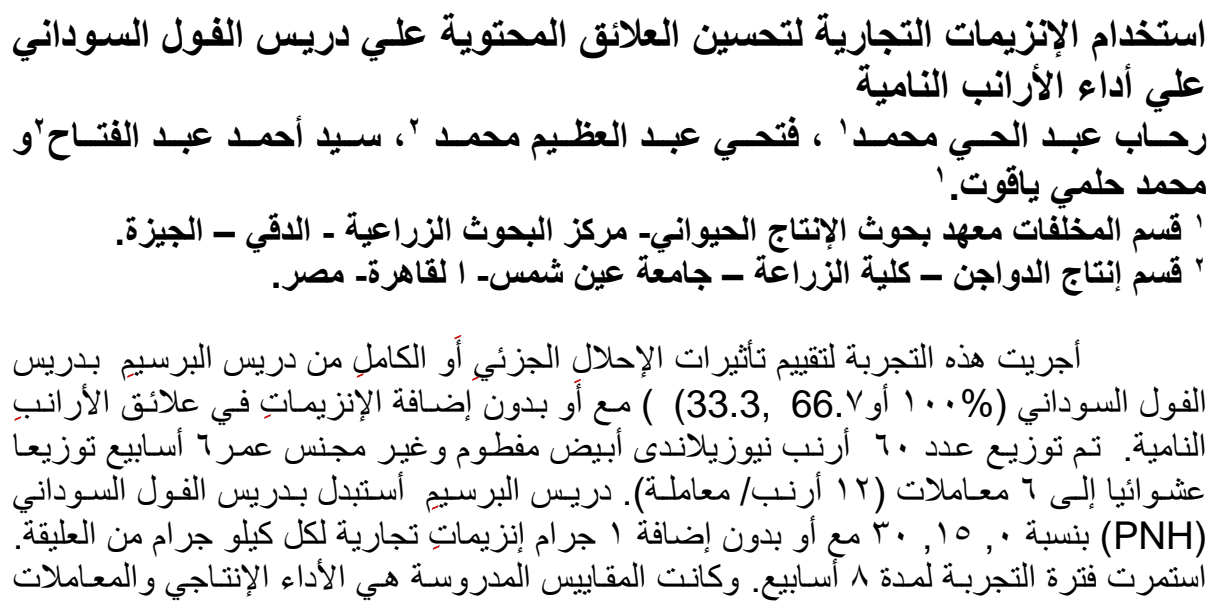


الهضــية للعناصـر الغذائيـة ومو اصـفات الذبيحة وبعض مكونـات الدم وأخير ا الكفـاءة الاقتصـادية.

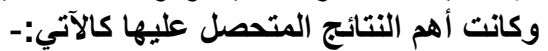

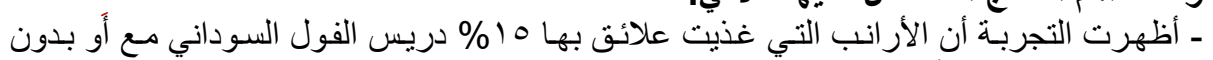

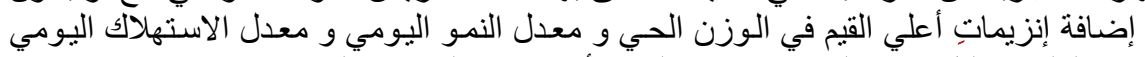

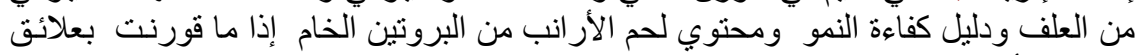

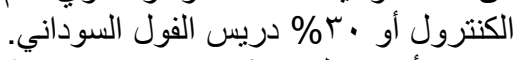

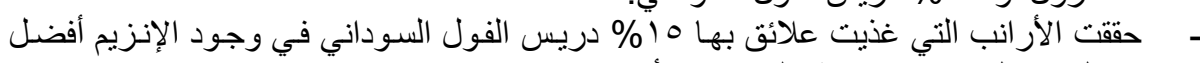

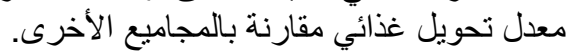

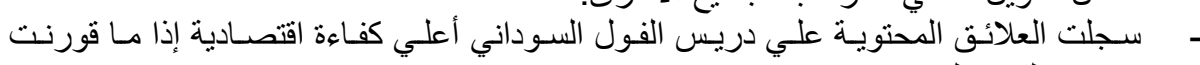

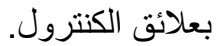

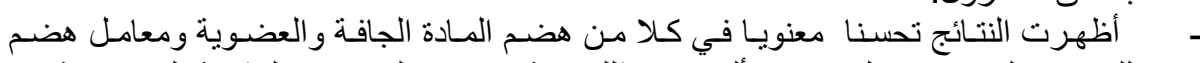

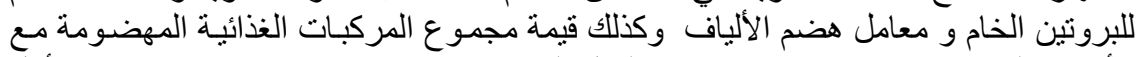

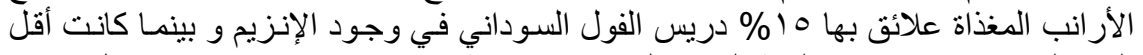

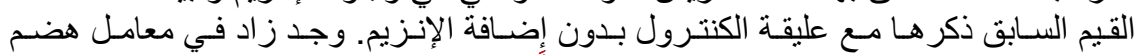

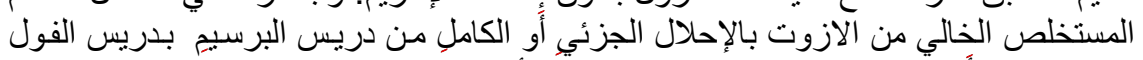

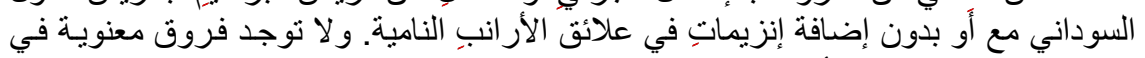

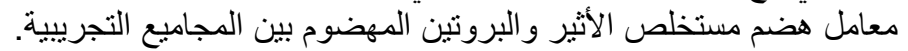

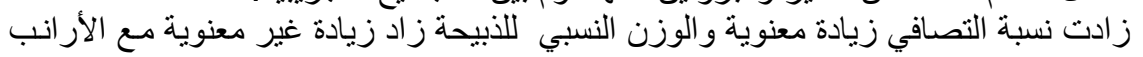

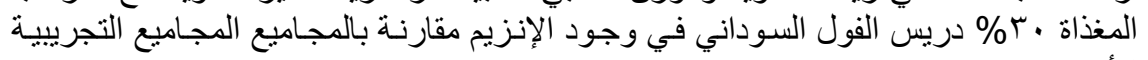
الأخرى.

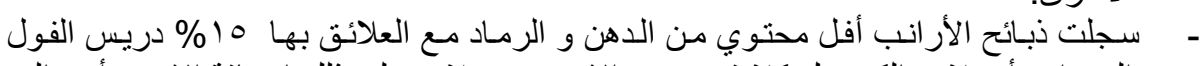

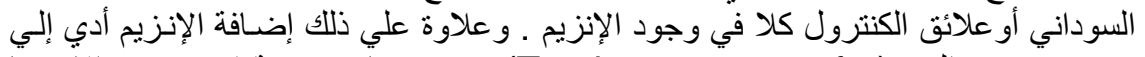

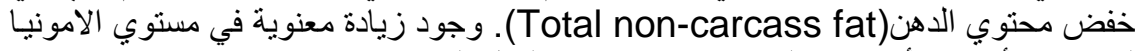

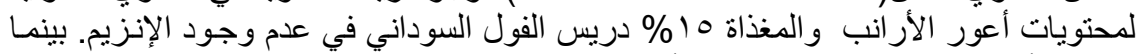

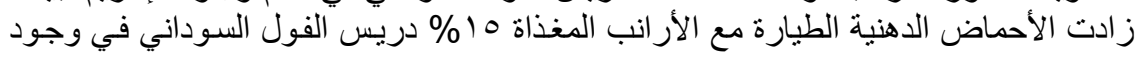

الإنزيم.

لا توجد فروق معنوية في مستوى كلا من البروتين الكلى والالبيومين في بلازما الدم وكذللك إنزيمات نشاط الكبد (AST\&ALT) بين المجاميع التجريبية.

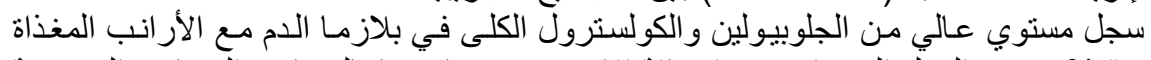

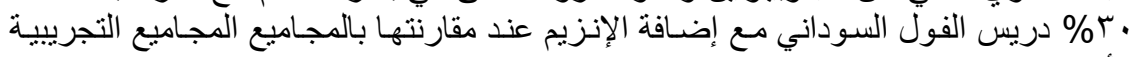

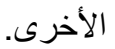

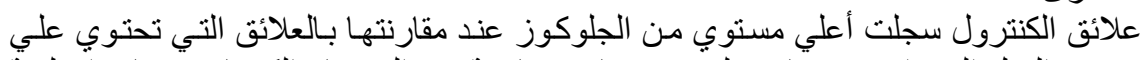

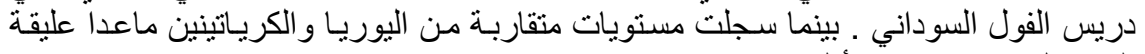

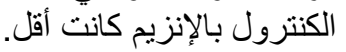

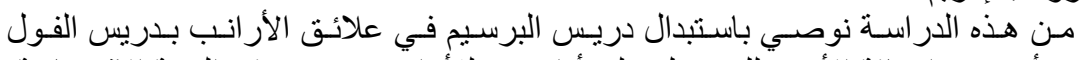

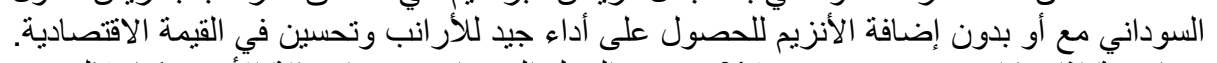

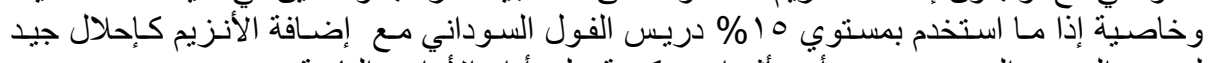
لدريس البرسيم المصري بدون أي تأثيرات عكسية علي أداء الأرانب النامية. 
Table(3) : Effect of feeding different levels of peanut hay (PNH) on growth performance of rabbits.

\begin{tabular}{|c|c|c|c|c|c|c|c|}
\hline Items & Control & Control +E & $15 \%$ PNH & $15 \% \mathrm{PNH}+\mathrm{E}$ & $30 \%$ PNH & $30 \% \mathrm{PNH}+\mathrm{E}$ & Sig. \\
\hline \multicolumn{8}{|c|}{ Live body weight (gm) at: } \\
\hline 6 weeks & $957.78 \pm 38.3$ & $957.78 \pm 24.9$ & $955.56_{ \pm 43.94}$ & $957.78 \pm 21.00$ & $956.67 \pm 29.63$ & $954.44 \pm 25.66$ & NS \\
\hline 14 weeks & $2417.8^{\mathrm{C}} \pm 66.9$ & $2425.3^{C_{ \pm 123.2}}$ & $2700.0^{\mathrm{b}_{ \pm}}+35.1$ & $2874.4^{\mathrm{a}} \pm 66.52$ & $2505.6^{b c} \pm 61.1$ & $2520.0^{b c_{ \pm}}+8.2$ & ** \\
\hline \multicolumn{8}{|c|}{ Daily weight gain (gm) from: } \\
\hline 6-14 weeks & $26.07^{\mathrm{C}} \pm 1.22$ & $26.21^{C_{ \pm 1}} .78$ & $31.15^{b} \pm 1.11$ & $34.23^{\mathrm{a}} \pm 1.06$ & $27.66^{C_{ \pm}} \pm 0.79$ & $27.95^{\circ} \pm 1.32$ & ** \\
\hline \multicolumn{8}{|c|}{ Daily feed consumption (gm/rabbit): } \\
\hline 14 weeks & $85.93^{C} \pm 2.44$ & $95.56 b_{ \pm 1.39}$ & $99.26^{a_{ \pm 1.08}}$ & $100.01^{a_{ \pm 1}} .24$ & $94.07^{\mathrm{b}} \pm 1.98$ & $93.70^{\mathrm{b}} \pm 1.17$ & ** \\
\hline \multicolumn{8}{|c|}{ Feed conversion ratio (FCR) from } \\
\hline 6-14 weeks & $3.32^{b} \pm 0.09$ & $3.77^{\mathrm{ab}} \pm 0.25$ & $3.21^{\mathrm{C}} \pm 0.10$ & $2.95^{\mathrm{C}} \pm 0.11$ & $3.4^{a b_{ \pm 0.07}}$ & $3.42^{a b_{ \pm 0.18}}$ & ** \\
\hline Total return (LE) & $21.90 \pm 1.02$ & $23.08 \pm 1.20$ & $23.7 \pm 0.88$ & $18.4 \pm 1.04$ & $18.45 \pm 1.04$ & $18.36 \pm 0.34$ & ** \\
\hline Net return (LE) & $14.61^{\mathrm{c}} \pm 0.88$ & $14.4^{\mathrm{c}} \pm 41.09$ & $18.22^{\mathrm{b}} \pm 0.88$ & $20.19^{b} \pm 0.92$ & $16.2^{\mathrm{bc}} \pm 0.58$ & $15.9^{\mathrm{bc}} \pm 1.09$ & ** \\
\hline $\begin{array}{l}\text { Economic } \\
\text { efficiency (\%) }\end{array}$ & $199.9^{b} \pm 8.96$ & $166.1^{c} \pm 10.6$ & $229.0^{\mathrm{ab}} \pm 9.9$ & $236.4^{\mathrm{ab}} \pm 12$ & $231.7^{\mathrm{ab}} \pm 7.3$ & $213.1^{\mathrm{ab}} \pm 14$ & ** \\
\hline Performance index & $44.63^{c} \pm 3.39$ & $42.6^{\mathrm{c}} 8 \pm 4.47$ & $55.14^{\mathrm{b}} \pm 3.44$ & $66.28^{\mathrm{a}} \pm 4.27$ & $45.7^{\mathrm{bc}} \pm 2.14$ & $47.52^{\mathrm{b}} \pm 4.17$ & ** \\
\hline
\end{tabular}

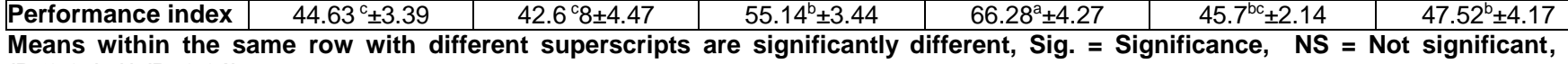

$(\mathrm{P} \leq 0.05)$, ** $(\mathrm{P} \leq 0.01)$.

Control $+\mathrm{E}=$ Control with enzyme , $\mathrm{PNH}=$ peanut hay, $\mathrm{PNH}+\mathrm{E}=$ Peanut hay with enzyme

Selling price of one $\mathrm{kg}$ live body weight=15.0 LE

Table (4) Effect of dietary peanut hay (PNH) levels on nutrients digestibility coefficients and nutritive values of growing rabbits.

\begin{tabular}{|c|c|c|c|c|c|c|c|}
\hline Items & Control & Control +E & $15 \%$ PNH & $15 \%$ PNH+E & $30 \%$ PNH & $30 \% \mathrm{PNH}+\mathrm{E}$ & Sig. \\
\hline \multicolumn{8}{|c|}{ Nutrients digestibility coefficients:- } \\
\hline Dry matter (DM) & $58.79^{\mathrm{c}} \pm 0.22$ & $59.38^{c} \pm 0.59$ & $61.40^{\mathrm{b}} \pm 0.38$ & $63.85^{a} \pm 0.23$ & $59.09^{c} \pm 0.11$ & $61.65^{\mathrm{ab}} \pm 0.57$ & ** \\
\hline Organic matter (OM) & $61.99^{\mathrm{c}} \pm 0.21$ & $62.74^{\mathrm{C}} \pm 0.31$ & $65.09^{b} \pm 0.28$ & $66.95^{a} \pm 0.23$ & $62.85^{c} \pm 0.10$ & $65.32^{\mathrm{b}} \pm 0.49$ & ** \\
\hline Crude protein $(\mathrm{CP})$ & $59.30^{c} \pm 0.35$ & $61.18^{\mathrm{b}} \pm 0.57$ & $61.35^{\mathrm{b}} \pm 0.48$ & $63.32^{\mathrm{a}} \pm 0.38$ & $59.55^{c} \pm 0.17$ & $61.09^{b} \pm 0.5$ & ** \\
\hline Ether extract (EE) & $77.00 \pm 0.77$ & $78.08 \pm 0.89$ & $78.29 \pm 0.27$ & $79.34 \pm 0.15$ & $77.47 \pm 0.11$ & $78.00 \pm 0.73$ & NS \\
\hline Crude fiber (CF) & $34.79^{\mathrm{c}} \pm 0.42$ & $34.61^{\mathrm{b}} \pm 0.51$ & $37.64^{b} \pm 0.83$ & $41.70^{\mathrm{a}} \pm 0.03$ & $31.85^{\mathrm{d}} \pm 0.16$ & $39.42^{\mathrm{b}} \pm 0.55$ & ** \\
\hline Nitrogen free extract (NFE) & $66.92^{\mathrm{d}} \pm 0.55$ & $66.77^{d} \pm 0.58$ & $70.36^{b} \pm 0.19$ & $71.71^{a} \pm 0.29$ & $68.85^{\mathrm{C}} \pm 0.21$ & $70.58^{\mathrm{ab}} \pm 0.50$ & ** \\
\hline \multicolumn{8}{|c|}{ Nutritive values:- } \\
\hline Total digestible nutrients (TDN) & $60.79^{\mathrm{C}} \pm 0.17$ & $61.46^{\mathrm{c}} \pm 0.28$ & $63.90^{\mathrm{b}} \pm 0.27$ & $65.58^{\mathrm{a}} \pm 0.21$ & $61.70^{c} \pm 0.12$ & $63.70^{b} \pm 0.49$ & ** \\
\hline Digestible crude protein (DCP) & $9.24 \pm 0.06$ & $9.34 \pm 0.05$ & $9.48 \pm 0.07$ & $9.71 \pm 0.06$ & $9.13 \pm 0.01$ & $9.30 \pm 0.08$ & NS \\
\hline
\end{tabular}

Control $+\mathrm{E}=$ Control with enzyme , $\mathrm{PNH}=$ peanut hay, $\mathrm{PNH}+\mathrm{E}=$ Peanut hay with enzyme 
Table (5) : Effect of dietary peanut hay (PNH) levels on carcass traits and ceacum activity of rabbits.

\begin{tabular}{|c|c|c|c|c|c|c|c|}
\hline Traits & Control & Control +E & $15 \%$ PNH & $15 \% \mathrm{PNH}+\mathrm{E}$ & $30 \%$ PNH & $30 \% \mathrm{PNH}+\mathrm{E}$ & Sig \\
\hline Dressing percentage \# & $62.43^{b} \pm 0.81$ & $63.22^{\mathrm{b}} \pm 1.55$ & $61.08^{b} \pm 0.73$ & $64.63^{\mathrm{b}} \pm 1.51$ & $64.80^{b} \pm 2.52$ & $67.48^{a} \pm 1.06$ & * \\
\hline Hot Carcass weight (\%) & $52.17 \pm 1.36$ & $53.34 \pm 1.62$ & $50.94 \pm 1.28$ & $55.15 \pm 2.43$ & $54.96 \pm 2.66$ & $57.15 \pm 0.99$ & NS \\
\hline Giblets weight (\%) & $4.01 \pm 0.36$ & $3.98 \pm 0.13$ & $3.57 \pm 0.50$ & $3.73 \pm 0.16$ & $3.30 \pm 0.13$ & $4.18 \pm 0.08$ & NS \\
\hline Head weight (\%) & $6.25 \pm 0.35$ & $5.90 \pm 0.14$ & $6.57 \pm 0.39$ & $5.72 \pm 0.21$ & $6.54 \pm 0.14$ & $6.15 \pm 0.14$ & NS \\
\hline Blood weight (\%) & $3.50 \pm 0.57$ & $3.57 \pm 0.52$ & $4.24 \pm 0.10$ & $3.43 \pm 0.32$ & $4.05 \pm 1.51$ & $3.10 \pm 0.52$ & NS \\
\hline Total non-carcass fat (\%) & $0.45^{\mathrm{b}} \pm 0.04$ & $0.36^{\mathrm{c}} \pm 0.02$ & $0.59^{\mathrm{a}} \pm 0.03$ & $0.43^{\mathrm{b}} \pm 0.01$ & $0.69^{\mathrm{b}} \pm 0.02$ & $0.48^{\mathrm{b}} \pm 0.01$ & * \\
\hline \multicolumn{8}{|l|}{ Caecum activity:- } \\
\hline pH caecum (\%) & $6.48 \pm 0.04$ & $6.46 \pm 0.06$ & $6.42 \pm 0.03$ & $6.39 \pm 0.06$ & $6.49 \pm 0.02$ & $6.49 \pm 0.02$ & NS \\
\hline pH stomach (\%) & $3.25 \pm 0.19$ & $3.47 \pm 0.07$ & $2.26 \pm 0.06$ & $3.55 \pm 0.03$ & $3.68 \pm 0.02$ & $3.68 \pm 0.02$ & NS \\
\hline $\mathrm{NH}_{3}(\mathrm{mg} / 100 \mathrm{ml})$ & $24.58^{\mathrm{bc}} \pm 0.81$ & $23.37^{c} \pm 0.59$ & $28.89^{\mathrm{a}} \pm 1.24$ & $25.88^{\mathrm{b}} \pm 0.09$ & $26.17^{b} \pm 0.31$ & $26.17^{b} \pm 0.31$ & 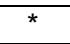 \\
\hline TVFA(mq/100 ml) & $99.53^{\mathrm{b}} \pm 0.98$ & $103.33^{b} \pm 1.81$ & $105.47^{b} \pm 2.43$ & $115.67^{a} \pm 4.70$ & $101.90^{\mathrm{b}} \pm 0.81$ & $101.90^{\mathrm{b}} \pm 0.81$ & * \\
\hline \multicolumn{8}{|c|}{ Proximate analysis of rabbits meat:- } \\
\hline Dry matter (DM) & $33.1 \pm 0.41$ & $33.2 \pm 0.35$ & $33.3 \pm 0.24$ & $33.8 \pm 0.15$ & $34.1 \pm 0.23$ & $34.43 \pm 0.25$ & NS \\
\hline Crude protein $(\mathrm{CP})$ & $64.69^{b c} \pm 0.6$ & $65.33^{\mathrm{b}} \pm 0.59$ & $66.98^{\mathrm{a}} \pm 0.18$ & $67.12^{\mathrm{a}} \pm 0.14$ & $64.85^{\mathrm{bc}} \pm 0.3$ & $63.99^{\mathrm{c}} \pm 0.23$ & ** \\
\hline Ether extract (EE) & $16.74^{\mathrm{b}} \pm 0.36$ & $15.92^{c} \pm 0.13$ & $17.70^{\mathrm{a}} \pm 0.09$ & $16.69^{b} \pm 0.26$ & $18.08^{\mathrm{a}} \pm 0.23$ & $17.47^{\mathrm{a}} \pm 0.21$ & *夫 \\
\hline Crude ash & $16.57^{\mathrm{cd}} \pm 0.3$ & $16.01^{\mathrm{d}} \pm 0.36$ & $17.78^{\mathrm{ab}} \pm 0.1$ & $16.30^{\mathrm{cd}} \pm 0.3$ & $18.44^{\mathrm{a}} \pm 0.23$ & $17.17^{\mathrm{bc}} \pm 0.4$ & ** \\
\hline
\end{tabular}

Means within the same row with different superscripts are significantly different. NS = Not significant ${ }^{*}(P<0.05) \quad{ }^{* *}(P<0.01)$

Dressing percentage\# included relative weights of carcass, giblets and head.

Control $+\mathrm{E}=$ Control with enzyme , $\mathrm{PNH}=$ peanut hay, $\mathrm{PNH}+\mathrm{E}=$ Peanut hay with enzyme.

Table (6) : Effect of dietary peanut hay (PNH) levels on some blood biochemical components of growing rabbits.

\begin{tabular}{|c|c|c|c|c|c|c|c|}
\hline Traits & Control & Control +E & $15 \%$ PNH & $15 \% \mathrm{PNH}+\mathrm{E}$ & $30 \%$ PNH & $30 \% P N H+E$ & Sig. \\
\hline Total protein (g/dl) & $6.79 \pm 0.13$ & $7.00 \pm 0.08$ & $6.84 \pm 0.19$ & $7.19 \pm 0.05$ & $7.20 \pm 0.13$ & $7.19 \pm 0.07$ & NS \\
\hline Albumin (g/dl) & $4.29 \pm 0.09$ & $4.37 \pm 0.07$ & $4.39 \pm 0.12$ & $4.51 \pm 0.04$ & $4.55 \pm 0.10$ & $4.31 \pm 0.14$ & NS \\
\hline Globulin (g/dl) & $2.50^{\mathrm{bc}} \pm 0.04$ & $2.63^{b c} \pm 0.001$ & $2.45^{\mathrm{c}} \pm 0.18$ & $2.68^{b} \pm 0.01$ & $2.65^{b} \pm 0.03$ & $2.88^{a} \pm 0.08$ & ** \\
\hline A/G ratio & $1.71^{a} \pm 0.01$ & $1.67^{a} \pm 0.03$ & $1.73^{a} \pm 0.02$ & $1.69^{a} \pm 0.01$ & $1.72^{\mathrm{a}} \pm 0.02$ & $1.49^{b} \pm 0.09$ & ** \\
\hline Cholesterol (mg/dl) & $86.69^{\mathrm{c}} \pm 1.4$ & $81.96^{\mathrm{d}} \pm 0.11$ & $89.50^{b} \pm 0.57$ & $85.24^{c} \pm 0.55$ & $92.32^{a} \pm 0.93$ & $85.34^{c} \pm 0.80$ & ** \\
\hline glucose $(\mathrm{mg} / \mathrm{dl})$ & $79.32^{\mathrm{ab}} \pm 0.84$ & $81.07^{a} \pm 0.46$ & $77.98^{\mathrm{b}} \pm 1.09$ & $79.51^{\mathrm{ab}} \pm 0.29$ & $74.77^{\mathrm{c}} \pm 0.42$ & $77.65^{\mathrm{b}} \pm 0.74$ & ** \\
\hline Urea (mg/dl) & $41.03^{a} \pm 0.97$ & $39.01^{b} \pm 0.25$ & $41.94^{\mathrm{a}} \pm 0.95$ & $41.38^{a} \pm 0.43$ & $40.99^{a} \pm 0.52$ & $42.28^{a} \pm 0.21$ & ** \\
\hline Creatinine (mg/dl) & $0.94^{b c} \pm 0.02$ & $0.87^{\mathrm{c}} \pm 0.02$ & $1.02^{\mathrm{ab}} \pm 0.04$ & $1.00^{\mathrm{ab}} \pm 0.03$ & $0.97^{a b} \pm 0.02$ & $1.04^{a} \pm 0.03$ & ** \\
\hline Hemoglobulin (g/L) & $13.55^{\mathrm{a}} \pm 0.14$ & $13.56^{\mathrm{a}} \pm 0.04$ & $13.28^{\mathrm{ab}} \pm 0.07$ & $13.30^{\mathrm{ab}} \pm 0.09$ & $13.02^{\mathrm{b}} \pm 0.15$ & $13.11^{\mathrm{b}} \pm 0.07$ & ** \\
\hline
\end{tabular}




\begin{tabular}{|c|c|c|c|c|c|c|c|}
\hline AST $(\mu / L)$ & $30.14 \pm 0.94$ & $31.34 \pm 1.12$ & $31.55 \pm 2.18$ & $31.43 \pm 1.94$ & $32.47 \pm 1.26$ & $32.66 \pm 1.53$ & NS \\
\hline ALT $(\mu / L)$ & $36.65 \pm 0.45$ & $39.19 \pm 0.24$ & $38.09 \pm 0.75$ & $38.18 \pm 1.18$ & $38.91 \pm 1.18$ & $40.33 \pm 0.27$ & NS \\
\hline
\end{tabular}

Control $+E=$ Control with enzyme , $\mathrm{PNH}=$ peanut hay, $\mathrm{PNH}+\mathrm{E}=$ Peanut hay with enzyme. 